\title{
Long-distance library service for a graduate school
}

\author{
By Andy Corrigan \\ Public Services Librarian, College of Graduate Studies \\ University of West Virginia
}

\section{Many graduate students receive services and materials by phone and mail.}

W est Virginia has a long history of economic trouble. Even recent times have been marked by chronic high unemployment. Steep hills wrap around many communities like the Chinese wall, keeping hard times at home and prosperity out. These communities need education, including graduate programs for the continuing education of their teachers, counselors, and business managers.

For 17 years the University of West Virginia College of Graduate Studies (COGS) has been chipping away at this problem, bringing innovative graduate programs to students working and living in communities throughout the southern and central regions of the state.

Library services for many of these graduate students are provided from a distance. Thus, the COGS library, known as Information Services, has evolved into an operation radically different from traditional libraries serving graduate programs. In short, Information Services delivers.

Students and faculty at a distance can mail or call in requests for bibliographic searches and books, journal articles, or documents. The requests are quickly processed at the library and the requested material is sent back through the mail. While these services involve assistance from new library technologies, Information Services relies most heavily on the telephone and the good old United States Postal Service.

\section{The college}

Today, the University of West Virginia College of Graduate Studies offers master's degree programs in education, behavioral science, business administration, humanities, and engineering. Enrolled are 3,000 students from 46 of the state's 55 counties. The largest percentage of these students, $76 \%$, are enrolled in education courses. Many are already teachers.

The median age for COGS students is 36 . Most of them work full-time and are enrolled in the college part-time. Two-thirds of the total enrollment are students living outside of Kanawha County, where COGS is based on the campus of West Virginia State College (WVSC) in Institute. The COGS/WVSC campus is near the center of the state, located nine miles west of Charleston, the state capital.

Each semester, about 150 COGS courses are offered at the Institute campus. The college offers nearly as many courses out of branch offices and more than 20 course sites at strategic locations around the state. These locations include Beckley 
College campus in Beckley, the Concord College campus in Athens, the Bluefield State College campus in Bluefield, the Glenville State College Nicholas County Center in Summersville, and the School of Osteopathic Medicine in Lewisburg.

In recent years COGS has cooperated with other West Virginia colleges and universities to offer graduate-level teleconference courses over an educational satellite network. Also, about 120 students are enrolled in a cooperative doctoral education program offered jointly by COGS and West Virginia University.

\section{Information services}

At COGS, non-traditional free library services for students and faculty at a distance include:

- phone-in reference service via a toll-free number and PC access to the library's online cata$\log$;

- liberal distribution of specialized computergenerated bibliographies (at least one available to each student per course per semester);

- delivery by mail of books and copies of journal articles or documents owned by the library and "automatic" access to interlibrary loan for items not owned;

- an electronic bulletin board over which students can retrieve library information;

- reserve collections at 15 regular sites. Alternative sites can be arranged, too.

Information Services helps provide traditional library services at the Drain-Jordan library on the Institute campus. The library is operated jointly and shared by COGS and WVSC, which are separate institutions.

The Drain-Jordan library houses the combined collections of COGS and WVSC, which include 230,000 book volumes and 2,000 journal titles. A VTLS online catalog, 14 microfilm printers, and three paper copiers help visitors to quickly find, check out or make copies of items for educational use. The reference area offers access to nine bibliographic or informational databases at four CDROM workstations. The CD databases include ERIC, PsycLit, Sociofile, ABI-Inform, MLA, Agricola, Dissertation Abstracts, County and City Data Book, and U.S. Census data. Students visiting the library often live hours away and drive through many miles of steep, twisting hollows to get there. Librarians work to make these visits as productive as possible, recognizing that returning to the library the next day is not an option for many students.

The two colleges have separate staffs serving the library. Information Services (COGS) librarians share general reference duties with their WVSC colleagues in addition to providing specialized services for graduate students at the library and at a distance. The WVSC librarians often provide general help to COGS students in the library and, ideally, refer them to Information Services librarians for searches or help in obtaining materials from outside sources.

The COGS students using long-distance library services can accomplish most of their research without actually traveling to the library. Still, Information Services encourages its students who can to make the trip at least a few times, if only for the hands-on experience.

Information Services collects material to support COGS's graduate programs. The WVSC library collects to support its college's undergraduate programs. The two library organizations within the same building have different missions and provide different levels of service for their students and faculty. The combination is cost-effective and provides the library with more material and staff than each organization could provide alone.

The Information Services staff at the DrainJordan library includes two professional librarians. They are assisted by five full-time technical staff, and three part-time document delivery assistants. One other librarian and two part-time secretaries staff a small Information Services office at the college's busiest extended campus site in Beckley. There, students 70 miles from the main library can meet face to face with a librarian to discuss their research, use a small collection, and have their requests for books and articles quickly transmitted by fax to Institute.

Students learn about the college's specialized library services from their instructors or from bibliographic instruction provided by COGS librarians. The librarians sometimes travel to distant sites to teach instruction sessions.

Informational handouts, often combined in packets, are widely distributed to students. Handouts include a general troubleshooter's guide to using the library at a distance; lists of library services and cooperating libraries; directions for dialing into the online catalog or electronic bulletin board; and more than a dozen updated guides for choosing research materials in specific subject areas.

\section{Access to knowledge}

To provide students, regardless of their proximity to the library, with knowledge of the range of material available on their research topics, each is offered "one free" bibliographic computer search per course per semester. The offer of one is flexible. No formal system exists for charging students for more than one search. The idea has been to discourage misuse of the service, which so far has not been a problem.

Searches result in a printout listing citations and abstracts for material relating to a student's topic. Librarians produce the printouts searching the 
online catalog, CD-ROM databases in the library, or any of the hundreds of databases available through Dialog or BRS.

Students can request searches over the phone or by filling out and mailing in an "InfoSearch" request form. These forms are available from the library and at course sites. The printouts are generally mailed back to the students within 24 hours. During FY1989-90, the two COGS librarians at Institute filled 456 search requests. Because some topics required information from more than one database, the requests actually required 610 separate searches.

Numbers of annual search requests over the tenyear period since 1980 ranged from a low of 210 in $1981-82$ to a high of 721 in 1986-87. The annual average was 427 . Public access to CD-ROM databases, particularly ERIC and PsycLit, has reduced the number of searches requested by students living near or traveling to the library in Institute.

Students use the toll-free phone number to contact COGS librarians to discuss searches, research problems or for answers to ready reference questions. On occasion, students living near one of several academic libraries in central and southern West Virginia are referred to items identified in collections near them. These libraries have agreements with Information Services to allow access to COGS students. Their holdings can be searched from Institute by dialing into a statewide VTLS network.

\section{We deliver}

The Information Services document delivery staff mails material from the library directly to students and instructors living more than 20 miles from Institute. The heavy volume of requests during peak periods makes the job difficult. It is not uncommon to see other staff members, including librarians, chipping in to "get the mail out."

Library users at a distance fill out request forms for the items they need, having obtained their bibliographic information from a computer search, an instructor's reading list, or from previous research. They mail the request forms to the Institute where document delivery workers find the items, package them, and mail them to the user's home or work address. When a book is requested, the entire book is mailed and a return label is enclosed in the parcel. When the request is for a journal article or ERIC document, a paper copy is made and mailed. Students are allowed to request up to 25 items per class per semester. The limit is waived for students preparing a master's thesis or a dissertation.

The document delivery staff includes one fulltime and two to three part-time workers. They can find, process, and mail more than 200 requests a day during mid-semester periods.
These busy workers processed 12,619 requests for items during FY1989-90. Since 1980 the annual total for documents delivered has ranged from a previous high of 11,749 in 1986-87 to a low of 7,300 in 1983-84. The annual average during the 1980s was 9,359 . During the second half of the decade the numbers increased about $25 \%$ over the average for the first 5 years. This was probably due to improved access to bibliographic information. The improvements included the provision of CDdatabases at the Drain-Jordan library and of an ERIC workstation that has been moved around to several distant course sites.

Each item request form has a line on which students write the last date they could receive the item and still use it. Items not available at the Drain-Jordan library are automatically sought through interlibrary loan or document suppliers if enough time is available. On each bibliographic printout, a librarian underlines in red items owned by the library. The document delivery staff can usually send out a requested article or book available at the library within 24 hours of receiving its request. Their goal is next-day service. Library users are cautioned that obtaining material not owned by the library from other sources can take ten days to two weeks.

Recognizing that graduate research demands access to material beyond that which COGS and WVSC have collected, Information Services borrows heavily from other libraries using the OCLC interlibrary loan subsystem. Its ILL technician routinely processes 300 or more OCLC transactions a month during midsemester periods. Twothirds of these transactions are borrowing requests sent to other libraries. To reduce reliance on interlibrary loan and comply with copyright limitations, articles from journals not owned are routinely purchased when available from commercial document suppliers.

Other library organizations are offering document delivery, too. Central Michigan University's Off-Campus Library Services also mails library material to students. ${ }^{1}$ Fax networks have been set up by many libraries to reach students or patrons in rural areas. Notable among these is an ambitious academic program initiated by Eastern Oregon State College and state library projects in Montana and Washington state. ${ }^{2}$

'Virginia Witucke, "Off-campus Library Services: Leading the Way," College \& Research Libraries News 51 (March 1990): 252-256.

${ }^{2}$ Patricia J. Cutright and Terry Edvalson, Online Reference and Document Delivery Service Library Network (Washington, D.C.: American Association of State Colleges and Universities, 1988), available as ED306926; Mary Moore, "Fax," American Libraries 19 (January 1988): 57-64. 
Somehow at COGS, however, long-distance delivery of library services seems less technical and more dependent on a small cast of dedicated characters. Providing library materials to students at a distance was a challenge posed to the library when COGS was just getting started. Information Services was built on tight budgets over many years by Dr. Sue Forrest. It was built around the college's mission of distance education.

It is difficult to separate the exact costs for Information Services's distance components. Annual postage fees, salaries for the document delivery staff and expenses for photocopies and envelopes roughly total around $\$ 30,000$-about $12 \%$ of an overall budget of $\$ 359,359$. Not included in the percentage are expenses for bibliographic searches and interlibrary loans incurred for distance students. These expenses are not separated from those for local students. The percentage of time spent by librarians managing document delivery or by other staff chipping in to help on busy days could also be factored in, if the information were easier to calculate. It is clear, however, that document delivery requires a substantial portion of a relatively small budget.

Despite its budget limitations, Information Services does not charge students fees for document delivery. In fact, it does not directly charge students for any of its services. Part of the reason is that staff time is not available to handle the accounting which fees would require. Another part is the reasonable philosophy that in West Virginia distance can be prohibitive enough to learning, without tacking on service charges above the cost of tuition and regular fees.

\section{Conclusion}

Information Services could not serve the college it supports without its delivery component, and periodic surveys have shown that its long-distance users appreciate very much the service and the efforts of those involved. Professionally, the library offers a satisfying sense that its staff is bringing valuable information to important people in areas where such information had not been accessible.

The college has fax machines at six sites including Information Services at Institute. The library's use of fax technology is limited to speeding requests for material to the main library when possible. Many students still must travel considerable distances over difficult terrain to reach these fax sites, or other locations where fax machines are available. Getting to class can be difficult enough. While at least one day slower than fax transmission, the postal service has proven itself reliable and egalitarian. Few COGS students are likely to own a fax machine, but each one owns a mailing address.

The librarians at Information Services are studying ways to continue to improve distance access to the library, and to meet a demand for increasing numbers of materials. Plans include expanding the information available through dial-up access to the library, providing library instruction by teleconference and building on cooperative efforts with other West Virginia libraries and schools.

\section{Improved academic libraries statistics}

Forty-three librarians, 33 state higher education administrators, and eight federal officials met in Chicago on October 18 and 19 to work out details of a plan to improve the quality and timeliness of national academic library statistics. Key components of this plan are cooperation between state higher education administrators and librarians and use of a new software package. Organized by an Advisory Committee of seven representatives from ACRL and the Association of Research Libraries, the meeting was funded by the National Center for Education Statistics (NCES) through a cooperative project with the National Commission on $\mathrm{Li}$ braries and Information Sciences (NCLIS). This was the first national meeting of state IPEDS Coordinators and the academic librarians or state library staff who will work with them to promote prompt responses from libraries and to assist in resolving errors discovered when editing completed questionnaires.

The most recent national collection of IPEDS data from academic libraries took place in the fall of
1988 and a summary report was published in September 1990 by the Government Printing Office. The new plan will enable NCES to publish data collected in the fall of 1990 by August 1991cutting in half the time it took for publication of the 1988 data.

NCES officials attending the meeting were Samuel Peng, Director of the Postsecondary Education Statistics Division, Larry LaMoure, Coordinator of the Library Statistics Program and Art Podolsky also of the Library Statistics Program, Bill Freund, Chief of the Institutional Studies Branch, and Charles Length of the NCES/State Higher Education Executive Officers Communication Network.

Peter Young, Executive Director of NCLIS, acted as a facilitator. Mary Alice Hedge Reszetar, Associate Executive Director of NCLIS, and John Lorenz, also of NCLIS, coordinated arrangements. Also present were Mary Jo Lynch of ALA's Office for Research who is Project Director and Mary Ellen Davis of ACRL, Assistant Director. 